\title{
Implementation of a system for the development of virtual exams at the Universidad de Ciencias y Humanidades under the PMBOK approach
}

\author{
Erick Canova-Rosales ${ }^{1}$, Margarita Giraldo-Retuerto ${ }^{2}$, Brian Malaver-Tuero ${ }^{3}$, Antonio Rojas-Meneses ${ }^{4}$, Enrique Lee \\ Huamaní ${ }^{5}$ \\ ${ }^{1}$ Systems Engineering Program, Universidad de Ciencias y Humanidades, Lima-Perú, ericanovar@uch.pe \\ ${ }^{2}$ Systems Engineering Program, Universidad de Ciencias y Humanidades, Lima-Perú, margiraldor@uch.pe \\ ${ }^{3}$ Systems Engineering Program, Universidad de Ciencias y Humanidades, Lima-Perú, margiraldor@uch.pe \\ ${ }^{4}$ Systems Engineering Program, Universidad de Ciencias y Humanidades, Lima-Perú, antrojasm@uch.pe \\ ${ }^{5}$ Image Processing Research Laboratory (INTI-Lab), Universidad de Ciencias y Humanidades, Lima-Perú, ehuamaniu@uch.edu.pe
}

\begin{abstract}
In the Universidad de Ciencias y Humanidades, under the events of the year 2020 regarding the global pandemic, new ways have emerged to develop classes through information technologies. Despite the efficiency of these tools there is still a limitation to the development of virtual exams because there is still a high percentage of probability that plagiarism occurs, therefore in this project was framed in the type of applied technology research where they used a series of techniques and tools for the implementation of a system for the development of virtual exams under the focus of the PMBOK, this research will argue the processes developed in the management for the development of the research project in order to contribute to the scientific community in the management of a software project.
\end{abstract}

Key words: Virtual Examinations, PMBOK, Project Management, Distance Learning, Software Development

\section{INTRODUCTION}

In the current pandemic everyone is teaching their classes at a virtual level, which is why the current situation requires an improvement in their virtual university platforms to adapt to the new demands of distance education. The general problem is to carry out evaluations of the exams of the different specialties of the Universidad de Ciencias y Humanidades in the heat of the distance education that by consequence it is necessary to know what procedures to take to evaluate the students in the different specialties, as the professors evaluated the exams of the students in the heat of the pandemic and what characteristics must have a good environment for the accomplishment of the virtual exams, Therefore, in this research we plan to evaluate the exams of the different specialties of the University in distance education, this will be done with the creation of a system that allows the taking of exams online and also allows the management of the tests done with a user-friendly platform. Its specific objectives of this research is to make the evaluation of the different specialties implementing a tool that facilitates the implementation of online exams for each specialty, make the teachers evaluate the students, this through a tool that allows the teacher to develop the exams virtually and provide a good environment for the development of virtual exams this through a system that has the comfort and design for easy use of the system for both those who make the exams as for those who provide them.

\section{USED TOOLS}

\subsection{JavaScript}

JavaScript is a programming language that allows you to perform complex activities on a web page - increasingly a web page does more than just display static information - such as displaying on-the-spot content updates, interacting with maps, graphic animations [1].

\subsection{NetBeans}

It is a standardized and modular integrated development tool (IDE), it is open source and it is a tool that can work in a variety of projects [2]. It is used in a variety of projects as demonstrated by research [3] that used this tool to have a fluid and well standardized code.

\subsection{Mysql}

Relational and multi-user database management system with more than six million installations On the one hand, it is offered under the GNUGPL for any use compatible with this license, but for those companies that want to incorporate it into proprietary products they must buy from the company a specific license that allows this use [4]. 


\section{$2.4 \mathrm{Html}$}

Elements in HTML (Hypertext Markup Language) are usually "block" or "inline" elements. An in-block element takes up all the space of its parent element (container), thus creating a "block". This article helps to explain what this means [5].

\section{USED TECHNIQUES}

\subsection{PMBOK}

The PMBOK can be divided into two sectors, which are Project Management Process, as well as the various knowledge areas, this means that it will work to manage several jobs in the time of the project cycle [6], Figure 1 shows the 5 phases of project management.

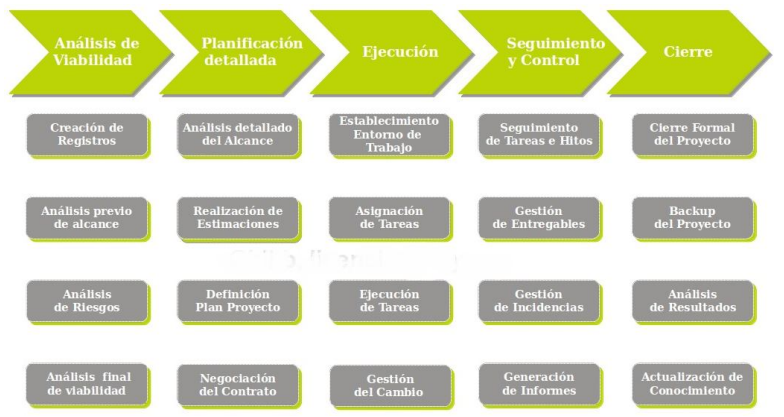

Figure 1: The 5 phases of project management

\subsection{Constitutional Act}

It is a document in which the scope of the objectives and the participants of the projects is defined. The roles are preliminary and are responsible for the objectives of the main stakeholders which defines the authority of the Project Manager. (GEDPRO) EDT It consists of various planning tools for the good management of projects, it is to define the scope of the same and the objectives, however it carries an adequate definition of the objectives or scope of the product [7].

It tries to define the work to be done, that is, what the scope will imply or decompose and this is achieved with the elaboration of the disaggregated structure of the work of the EDT project [8], in Figure 2 we see the project charter.

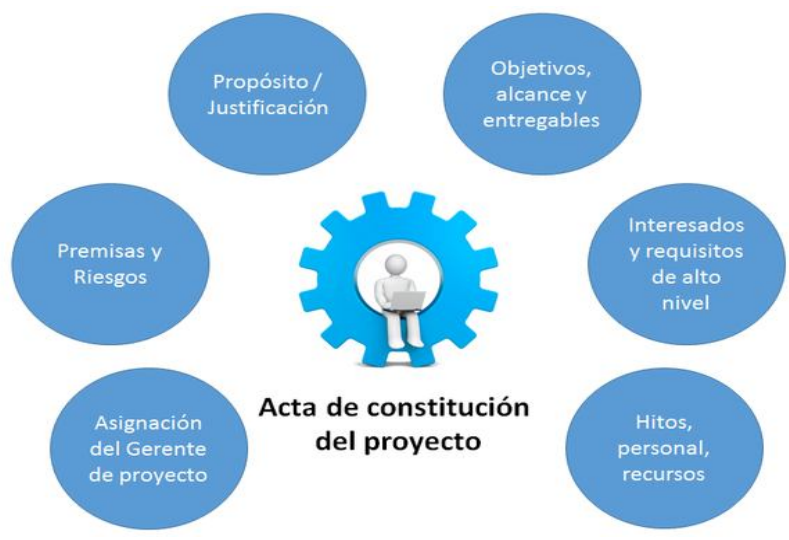

Figure 2: Project charter

\subsection{Life cycle}

Companies and authors often define and classify the phases of a project in several different ways, or more correctly in the project life cycle [9], in which the project is divided into five phases, as shown in Figure 3.

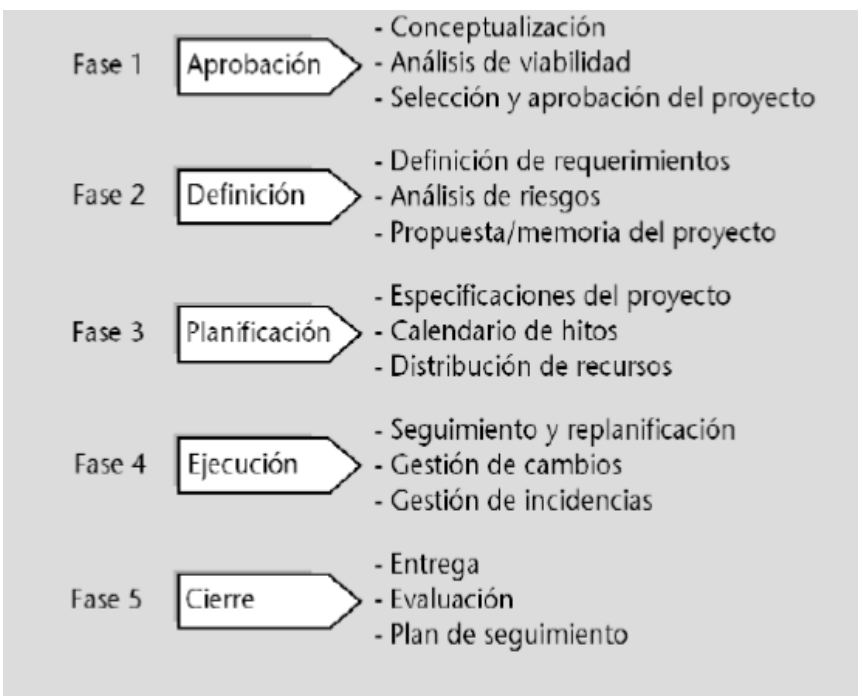

Figure 3: Project Life Cycle

The project cycle is not a linear process or a military ride. At the end of each phase, someone decides whether to continue or not, whether to change the work plan, resources, time or cost. This decision is usually made by the client, sponsor or person who has commissioned the work. But other times, the decision is up to the project manager or the company or department on which it depends. A responsible and sensible project manager must ask himself: can I and should I do or continue the project, am I in a position to meet the conditions of scope, quality, time and cost [10].

\subsection{Gant diagram}

It is a program for the planning of activities in a given period. Thanks to a comfortable and easy visualization of the planned actions, it allows to follow and control the progress of each 
Erick Canova-Rosales et al., International Journal of Emerging Trends in Engineering Research, 8(8), August 2020, 4044 - 4051

stage of a project, and also reproduces graphically the tasks, their duration and sequence. The beginning of a task that depends on the conclusion of a previous action will be represented with a link of the end-start type [11].

\section{DEVELOPMENT OF RESEARCH}

For the beginning of the development of every PMBOK oriented Project we must start with the constitution act as shown in Table 1 where it describes the title and description of the project and Table 2 that shows the assigned Project Director and the level and authority.

Table 1: Title and description of the project

\begin{tabular}{|c|c|c|}
\hline Project title & Project description & Data of the institution \\
\hline $\begin{array}{l}\text { Implement a system for the } \\
\text { development of virtual exams for } \\
\text { the Universidad de Ciencias } y \\
\text { Humanidades }\end{array}$ & $\begin{array}{l}\text { At the end of this project, it is expected to have a } \\
\text { tool that allows the improvement of the online } \\
\text { examinations, it has been decided to develop a new } \\
\text { application that allows the creation of enriched } \\
\text { tests, incorporation of images and videos, in a } \\
\text { more user-friendly environment. }\end{array}$ & $\begin{array}{l}\text { Name: Universidad de Ciencias y } \\
\text { Humanidades } \\
\text { Address: } 5175 \text { University Avenue, } \\
\text { Los Olivos (intersection with } \\
\text { Panamericana Norte) } \\
\text { Telephone: }(01) 5003100\end{array}$ \\
\hline
\end{tabular}

Table 2: Explanation of the project and case of functionality

\begin{tabular}{|c|c|}
\hline Mission & $\begin{array}{l}\text { We are a University that forms professionals through a proposal of integral education, } \\
\text { develops research, promotes culture and social projection; with the purpose of } \\
\text { contributing to the social and productive development of the country. }\end{array}$ \\
\hline Vision & $\begin{array}{l}\text { To be a reference university in research and comprehensive training of professionals } \\
\text { committed to the development of the country. }\end{array}$ \\
\hline Current problem of the study process & $\begin{array}{l}\text { Improve the process of taking exams online since there is an immediate demand for the } \\
\text { current situation of covid-19 virus in our country and worldwide that makes the classes } \\
\text { are done at a distance. }\end{array}$ \\
\hline Current activity flow & $\begin{array}{l}\text { - The student logs in with his/her ID and password to the platform. } \\
\text { - Select the course which will be evaluated. } \\
\text { - Access to the virtual exam, where the questions and time limit for the elaboration of } \\
\text { the exam are generated. } \\
\text { - At the end of the exam, the student will put the option to end the evaluation and send } \\
\text { their answers, in case the time is up, the selected answers will be automatically saved } \\
\text { and will be saved for the respective evaluation. } \\
\text { - The teacher takes exams through the UCH virtual classroom platform, in which he or } \\
\text { she can put the option to be evaluated as soon as the exam is finished; another way } \\
\text { will be the evaluation verified by the teacher, in which there may be questions that } \\
\text { will be answered with comments, in which the teacher must review and put the grade } \\
\text { at his or her discretion. }\end{array}$ \\
\hline
\end{tabular}


Erick Canova-Rosales et al., International Journal of Emerging Trends in Engineering Research, 8(8), August 2020, 4044 - 4051

\begin{tabular}{|l|l|}
\hline & $\begin{array}{l}\text { - The student will see if the evaluation will be evaluated at that time or will have a } \\
\text { review date. }\end{array}$ \\
\hline Describe the beneficiary & $\begin{array}{l}\text { Company name: Universidad de Ciencias y Humanidades } \\
\text { RUC number: 20516530767 Full name of person in charge }\end{array}$ \\
\hline
\end{tabular}


Erick Canova-Rosales et al., International Journal of Emerging Trends in Engineering Research, 8(8), August 2020, 4044 - 4051

Manage a tool to improve the performance of online exams in the same way that it allows the creation of enriched tests, incorporating images, in a friendly environment as shown in Table 3.

Tabla 3: Milestone Schedule Summary

\begin{tabular}{|c|c|}
\hline Deliverable & Week \\
\hline Constitutional Act & week 02 \\
\hline EDT Product prototype & week 03 \\
\hline $\begin{array}{l}\begin{array}{l}\text { Articles of Incorporation approved EDT } \\
\text { approved }\end{array} \\
\end{array}$ & week 04 \\
\hline Project Schedule & week 05 \\
\hline Integrated project plan 1 & week 06 \\
\hline Integrated project plan 2 & week 07 \\
\hline Detailed project budget & week 08 \\
\hline $\begin{array}{l}\text { Earned Value Report Execution: Performance } \\
\text { Report } 1\end{array}$ & week 09 \\
\hline $\begin{array}{l}\text { Quality Check Sheet Execution: Performance } \\
\text { Report } 2\end{array}$ & week 10 \\
\hline $\begin{array}{l}\text { HR and communications plan Execution: } \\
\text { Performance report } 3\end{array}$ & week 11 \\
\hline $\begin{array}{lrrr}\text { Risk } \quad \text { Management } & \text { Plan } & \text { Execution: } \\
\text { Performance Report } 4 & & \\
\end{array}$ & week 12 \\
\hline $\begin{array}{l}\text { Stakeholder and Procurement Plan Execution } \\
\text { Performance Report } 5\end{array}$ & week 13 \\
\hline Final report delivery & week 14 \\
\hline Deploying the solution & week 15 \\
\hline Constitutional Act & week 16 \\
\hline
\end{tabular}

Tabla 4: Measurable project objective

\begin{tabular}{|l|l|l|}
\hline Concept & Objective & Success criteria \\
\hline \multirow{5}{*}{ Scope } & $\begin{array}{l}\text { Create a system for the } \\
\text { best preparation and } \\
\text { execution of virtual exams } \\
\text { through the tools } \\
\text { established by the project } \\
\text { team }\end{array}$ & $\begin{array}{l}\text { Project with 100\% of } \\
\text { its activities executed } \\
\text { in the established } \\
\text { time. }\end{array}$ \\
\hline \multirow{3}{*}{ Weather } & $\begin{array}{l}\text { The project must be } \\
\text { completed in a maximum } \\
\text { of 14 weeks from the } \\
\text { Constitution Act. }\end{array}$ & $\begin{array}{l}\text { Completion date less } \\
\text { than 100 days from the } \\
\text { constitution of the } \\
\text { project. }\end{array}$ \\
\hline \multirow{3}{*}{ cost } & $\begin{array}{l}\text { The project must be } \\
\text { underway with a budget of } \\
\text { S/16000. }\end{array}$ & execution. \\
\hline
\end{tabular}

Tabla 5: High level risk

\begin{tabular}{|l|l|l|}
\hline \multicolumn{1}{|c|}{ Risk } & \multicolumn{1}{|c|}{ Consequence } \\
$\begin{array}{l}\text { Change in the } \\
\text { project team }\end{array}$ & $\begin{array}{l}\text { Higher cost for } \\
\text { resuming } \\
\text { activities and } \\
\text { tasks. }\end{array}$ & $\begin{array}{l}\text { Action } \\
\text { Correctly validate } \\
\text { the work equipment. }\end{array}$ \\
\hline $\begin{array}{l}\text { Lack of } \\
\text { availability of } \\
\text { the leader. }\end{array}$ & $\begin{array}{l}\text { It will delay the } \\
\text { project. }\end{array}$ & $\begin{array}{l}\text { Provide } \\
\text { information to the } \\
\text { team's support } \\
\text { consultant }\end{array}$ \\
\hline $\begin{array}{l}\text { Technology } \\
\text { and } \\
\text { communication } \\
\text { problems }\end{array}$ & $\begin{array}{l}\text { Delay of the } \\
\text { project ander-utilizatio } \\
\text { n of the tools } \\
\text { used. }\end{array}$ & $\begin{array}{l}\text { Verify the necessary } \\
\text { requirements for the } \\
\text { correct use of the } \\
\text { tools. }\end{array}$ \\
\hline $\begin{array}{l}\text { Changes } \\
\text { procedures } \\
\text { during } \\
\text { implementatio } \\
n\end{array}$ & $\begin{array}{l}\text { It will take a cost } \\
\text { overrun for } \\
\text { those interested } \\
\text { and time may } \\
\text { vary. }\end{array}$ & $\begin{array}{l}\text { Redesign } \\
\text { implementation or } \\
\text { track it to see if it } \\
\text { can be added } \\
\text { without } \\
\text { changes. }\end{array}$ \\
\hline
\end{tabular}

\subsection{Work breakdown structure}

It is the structure of decomposition of the work, it establishes the hierarchy and the deliverables of the project that we will elaborate.

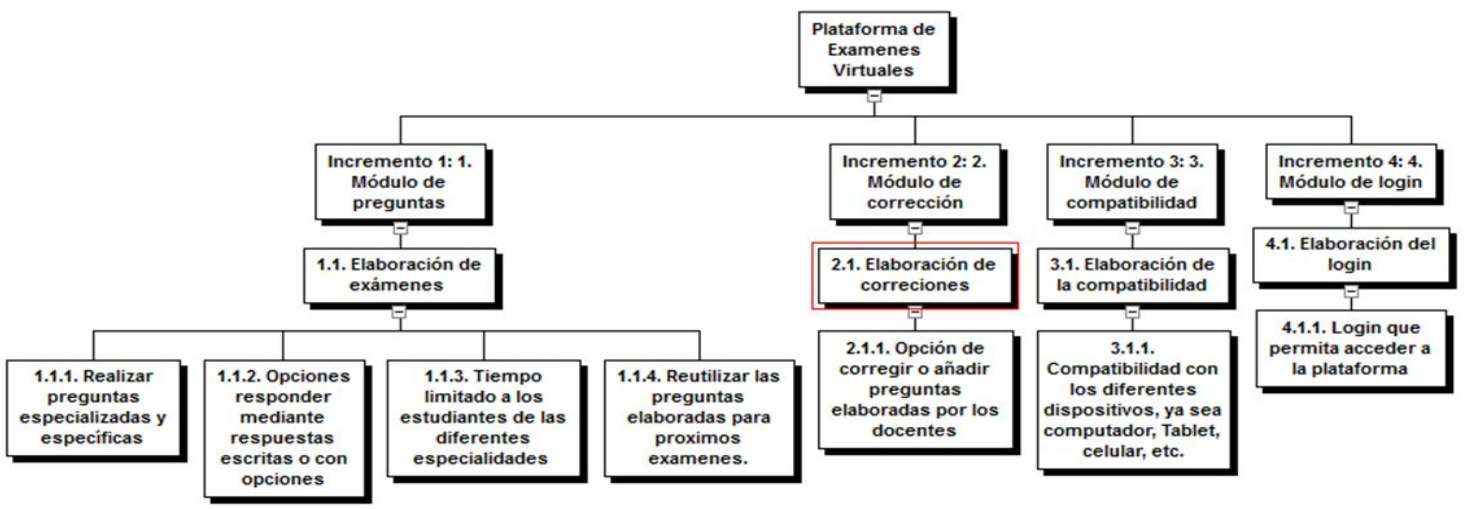

Figure 1: Architecture of the Enhanced Fuzzy Resolution Mechanism using ANFIS 
Erick Canova-Rosales et al., International Journal of Emerging Trends in Engineering Research, 8(8), August 2020, 4044 - 4051

\subsection{Time management}

In this area we will analyses the activities and the time it will take to carry out each one of them, analyzing the sequence of the activities, from the first activity, the one that starts the project function, to the last activity as shown in Table 8 .

Tabla 8: Project time management

\begin{tabular}{|l|l|}
\hline Activity & Name of the activity \\
\hline 1.1.1 & Ask specialized and specific questions \\
\hline A & Insert specialized questions \\
\hline B & Insert answers to each question \\
\hline C & Upload the complete exam (questions, answers) \\
\hline $\mathbf{1 . 1 . 2}$ & Options to respond through written answers or with options \\
\hline D & Enter the type of exam (written, with options, etc.) \\
\hline $\mathbf{1 . 1 . 3}$ & Time limited to students of the different specialities \\
\hline E & Enter date (day, month, year) of exam \\
\hline F & Enter start and end time of test \\
\hline $\mathbf{1 . 1 . 4}$ & Reuse the prepared questions for future exams. \\
\hline G & Save the questions and answers in the database \\
\hline $\mathbf{2 . 1 . 1}$ & Option to correct or add questions developed by teachers \\
\hline H & Correct or modify the questions \\
\hline I & Correcting or modifying answers \\
\hline $\mathbf{3 . 1 . 1}$ & Compatibility with different devices, whether computer, tablet, cell phone, etc. \\
\hline J & Create a responsive platform \\
\hline 4.1.1 & Login to access the platform \\
\hline K & Create username and password \\
\hline
\end{tabular}

Here the activities will be shown with their respective names, and the duration in days of each activity as shown in Figure 5.

\begin{tabular}{|c|c|c|c|}
\hline $\mathrm{N}^{\circ}$ de Actividad : & Nombre de la actividad & Duración (dias) & 国 \\
\hline 1.1 .1 & Realizar preguntas especializadas y especificas & 8 & $\nabla$ \\
\hline A & Insertar preguntas especializadas & 3 & \\
\hline B & Insertar respuestas a cadla pregunta & 3 & \\
\hline $\mathrm{C}$ & Subir el examen completo (preguntas, respuestas) & 2 & \\
\hline 1.1.2 & Opciones responder mediante respuestas escritas o con opciones & 4 & $\nabla$ \\
\hline D & Ingresar el tipo de examen (escrito, con opciones, etc.) & 4 & \\
\hline 1.1.3 & Tiempo limitado a los estudiantes de las diferentes especialidades & 4 & $\nabla$ \\
\hline$E$ & Ingresar fecha (día, mes, año) del examen & 2 & \\
\hline $\mathrm{F}$ & Ingresar hora de inicio y fin del examen & 2 & \\
\hline 1.1.4 & Reutilizar las preguntas elaboradas para próximos exámenes. & 5 & $\boldsymbol{\nabla}$ \\
\hline G & Guardar las preguntas y respuestas en la base de datos & 5 & \\
\hline 2.1.1 & Opción de corregir o añadir preguntas elaboradas por los docentes & 6 & $\nabla$ \\
\hline $\mathrm{H}$ & Corregir o modificar las preguntas & 3 & \\
\hline 1 & Corregir o modificar las respuestas & 3 & \\
\hline 3.1.1 & Compatibilidad con los diferentes dispositivos, ya sea computador, Tablet, celular, etc. & 3 & $\nabla$ \\
\hline $\mathrm{J}$ & Crear una plataforma responsive & 3 & \\
\hline 4.1.1 & Login que permita acceder a la plataforma & 2 & $\nabla$ \\
\hline K & Crear usuarios y contraseña & 2 & \\
\hline
\end{tabular}

Figure 5: Architecture of the Enhanced Fuzzy Resolution Mechanism using ANFIS 
Erick Canova-Rosales et al., International Journal of Emerging Trends in Engineering Research, 8(8), August 2020, 4044 - 4051

\subsection{Project network diagram Network diagram}

Tabla 9: Project time management

\begin{tabular}{|l|l|}
\hline Ruta & Duration (Days ) \\
\hline K-E-F-D-A-H-C & 18 \\
\hline K-E-F-D-A-B-I-C & 21 \\
\hline K-E-F-D-A-B-G-C & 23 \\
\hline J-C & 5 \\
\hline
\end{tabular}

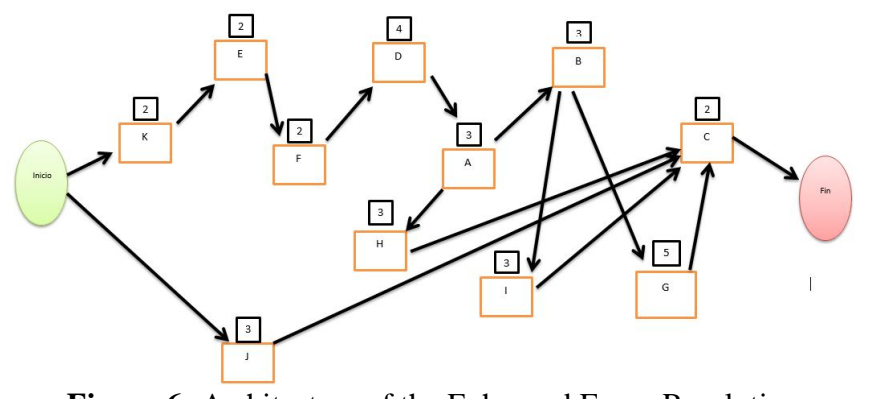

Figure 6: Architecture of the Enhanced Fuzzy Resolution Mechanism using ANFIS

\subsection{Critical path of the project network diagram}

Tabla 10: Project time management

\begin{tabular}{|l|l|l|}
\hline Activity & Previous activity & Estimated days \\
\hline INICIO & & 0 \\
\hline K & INICIO & 2 \\
\hline E & K & 2 \\
\hline F & E & 2 \\
\hline D & F & 4 \\
\hline A & D & 3 \\
\hline B & A & 3 \\
\hline G & B & 5 \\
\hline C & G,H,I,J & 2 \\
\hline H & A & 3 \\
\hline I & B & 3 \\
\hline J & INICIO & 3 \\
\hline FIN & C & 0 \\
\hline
\end{tabular}

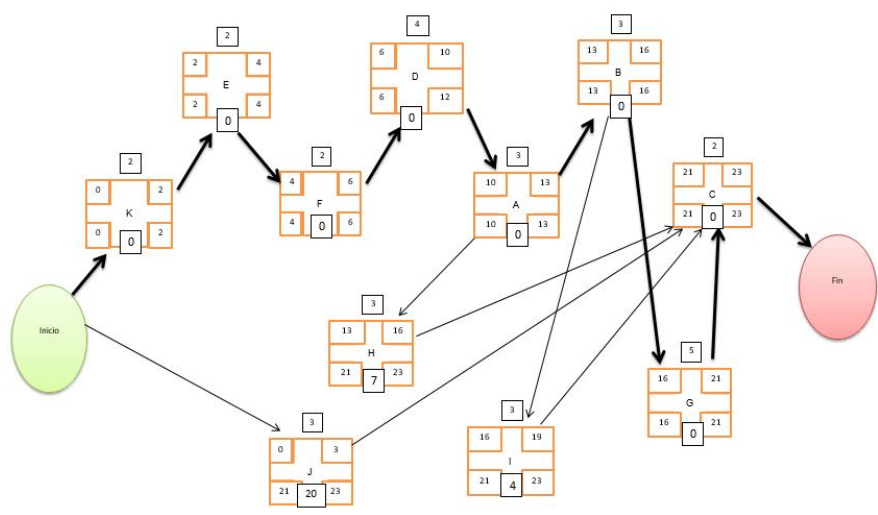

Figure 7: Architecture of the Enhanced Fuzzy Resolution Mechanism using ANFIS

\section{CONCLUSION}

Having carried out this project of development of Virtual Examinations as a strategy to improve the process of evaluation at a distance of the students of the University of Sciences and Humanities, leads us to reaffirm even more the importance of incorporating the technologies of information and communication in the processes of development of virtual examinations; so that the students carry out in a practical and immediate way the process of evaluation to contribute to the system of evaluation of the UCH.

This project allows students to maintain interest and be motivated to continue studying, since they are the protagonists of their own educational process, since the didactic evaluation is significant, participatory and productive.

Including online evaluation in the educational process is a powerful methodological resource that allows teacher-student interaction with the development of random questions in a dynamic way, thus contributing to raise the performance level of teachers of different specialties.

The development of virtual exams provides us with a user-friendly system that is easy to use for the teacher and student with a motivating design to undertake our evaluations.

Correctly detailing our system functionalities, determining the epics and user stories, we were able to successfully conclude the development of our virtual examination software.

\section{REFERENCES}

1. M. Vidakovic, S. Cosic, O. Cosic, I. Kastelan, and G. Velikic. One solution for execution of JavaScript in Java EE application servers, 2018 Zooming Innov. Consum. Technol. Conf. ZINC 2018, pp. 177-180, 2018. https://doi.org/10.1109/ZINC.2018.8448646

2. E. L. Huamaní, P. Condori, and A. Roman-Gonzalez. Implementation of a Beowulf Cluster and Analysis of its Performance in Applications with Parallel Programming, Int. J. Adv. Comput. Sci. Appl., vol. 10, no. 8, pp. 522-527, 2019.

3. Y. Cao, Z. Fang, Y. Yang, and Z. Li. Cutter database management system development on netbeans 5.0 platform, Proc. - 2009 1st Int. Work. Database Technol. Appl. DBTA 2009, pp. 41-44, 2009.

4. L. Zhang, H. Y. Ning, and Y. Yang. A new type MySQL integrated mutual authentication security model, Proc. 2016 6th Int. Conf. Instrum. Meas. Comput. Commun. Control. IMCCC 2016, pp. 253-257, 2016.

5. P. Skibiński. Improving HTML compression, Inform., 
vol. 33, no. 3, pp. 363-373, 2009.

6. S. Bayona, N. Saboya, and J. Bustamante. Application of PMBOK in the Development of Research, Iber. Conf. Inf. Syst. Technol. Cist., vol. June, pp. 1-5, 2018. https://doi.org/10.23919/CISTI.2018.8399340

7. N. Ehsan, O. A. Malik, F. Shabbir, E. Mirza, and M. Wasim Bhatti.Comparative study for PMBOK \& CMMI frameworks and identifying possibilities for integrating ITIL for addressing needs of IT service industry, 5th IEEE Int. Conf. Manag. Innov. Technol. ICMIT2010, pp. 113-116, 2010.

8. M. Manasy, K. N. Devika, and S. Murugan. Performance analysis of embedded deterministic test (EDT) on standard benchmark designs, Proc. 2017 IEEE Int. Conf. Technol. Adv. Power Energy Explor. Energy Solut. an Intell. Power Grid, TAP Energy 2017, pp. 1-5, 2018.

9. E. L. Huamaní, P. Condori, B. Meneses-Claudio, and A. Roman-Gonzalez. Render farm for highly realistic images in a beowulf cluster using distributed programming techniques, Int. J. Adv. Comput. Sci. Appl., vol. 10, no. 11, pp. 407-411, 2019. https://doi.org/10.14569/IJACSA.2019.0101156

10. Software \& Systems Eng. Standards Com. IEEE Computer Society. IEEE Guide - IEEE Std of Adoption ISO / IEC TR 24748-1 : 2010 Systems and Software Engineering - Life Cycle Management - Part 1: Guide for Life Cycle Management IEEE Computer Society, no. June 2011. 2010.

11. M. A. Hinojosa. Diagrama de Gantt - GestioPolis, 2003. 